\title{
MODELING DATA TRANSMISSION SYSTEMS USING MODERN INFORMATION TECHNOLOGIES
}

Manuscript received 26 May 2021;

Accepted 28 June 2021

\author{
Eleonora G. Akhmetshina, \\ Povolzhskiy state university of telecommunications \\ and informatics, Samara, Russia, \\ elyamalusha@mail.ru
}

\begin{abstract}
Keywords: IT GURU technologies, simulation modeling, analytical modeling, QS with time lag, average delay
\end{abstract}

\begin{abstract}
When modeling data transmission systems for various purposes, including computer and telecommunication networks, both components of mathematical modeling are widely used. These are simulation modeling and analytical modeling based on queuing theory. At the same time, researchers can always compare the results obtained by means of simulation and analytical modeling. From modern technologies of simulation modeling, one can single out the IT GURU Academic Edition technologies, represented by the Opnet Modeler and Riverbed Modeler software products with powerful graphical editors. Graphic editors allow you to create simulation models of data transmission systems of any complexity, and launch and run their models to obtain statistics of the main performance indicators of these systems. Comparison of the simulation results with the results of queuing systems (QS) of the G/G/I type makes it possible to assess the adequacy of those and other mathematical models. This article summarizes the results of the author's publications on $\mathbf{G} / \mathbf{G} / \mathbf{l}$ systems based on time-shifted distribution laws such as exponential, hyperexponential, and Erlang distribution. Thus, these distribution laws for the random variables used provide the coefficients of variation less than, equal or greater than one. This fact is important from the point of view of the queuing theory, because the average delay of claims in the system directly depends on the coefficients of variations in the time intervals for the arrival and servicing of claims.
\end{abstract}

Information about author:

Eleonora G. Akhmetshina, graduate student, Software department, Povolzhskiy state university of telecommunications and informatics, Samara Russia

\section{Для цитирования:}

Ахметшина Э.Г. Моделирование систем передачи данных с использованием современных информационных технологий // Т-Сотт: Телекоммуникации и транспорт. 202I. Том 15. №8. С. 52-57.

For citation:

Akhmetshina E.G. (202I) Modeling data transmission systems using modern information technologies. T-Comm, vol. I5, no.8, pp. 52-57. (in Russian) 


\section{Introduction}

When modeling data transmission systems methods and tools of mathematical modeling are widely used, including simulation and analytical modeling based on the queuing theory $[1,2,13]$. In imitation modeling, in the author's opinion, IT GURU Academic Edition technologies in the form of OPNET Modeler and RIVERBED Modeler software products are promising [3,4]. With the help of these software products, it is possible to simulate data transmission networks of varying degrees of complexity using a wide range of modern protocols.

In this article, in contrast to the classical theory of queuing, we consider QS with distribution laws shifted to the right from the zero point, such as exponential, hyperexponential and Erlang distribution. Such QSs are of the G/G/1 type, which are systems with general distribution laws of the intervals between claims of the input flow and the service time.

As is known, for $\mathrm{G} / \mathrm{G} / 1$ systems, it is impossible to obtain solutions for the main characteristic of the QS - the average delay of claims in the queue in the general case. Therefore, it is important to study such systems for special cases of distribution laws. The article provides an overview of the author's results for the average delay of claims in the queue for systems with input distributions shifted to the right from the zero point. To obtain them, we used the method of spectral decomposition of the solution of the Lindley integral equation [1].

The article summarizes and presents the spectral expansions of the solution to the Lindley integral equation for six systems and with their help are derived calculation formulas for the average delay of applications in the queue [6-10]. It is shown that in a queueing system with time lags, the average delay of claims is less than in conventional systems. The obtained calculation formulas for the average delay of claims extend and supplement the well-known unfinished formula of the queuing theory for the average delay of claims for systems $\mathrm{G} / \mathrm{G} / 1$. The proposed approach allows calculating the average latency for these systems in mathematical packets for a wide range of changes in traffic parameters.

Analysis of domestic and foreign scientific publications shows that there are few of them in the queueing system with time lags. In papers $[11,12]$ methods and techniques of moment approximation of distribution laws are presented. New advances in the theory of queuing are given in [14-17], but the closest in terms of topics to the queueing system with time lags is the work [14].

Further, the results obtained for the systems: $\mathrm{E}_{2}^{-} / \mathrm{E}_{2}^{-} / 1$, $\mathrm{E}_{2}^{-} / \mathrm{M}^{-} / 1, \mathrm{M}^{-} / \mathrm{E}_{2}^{-} / 1, \mathrm{H}_{2}^{-} / \mathrm{H}_{2}^{-} / 1, \mathrm{H}_{2}^{-} / \mathrm{M}^{-} / 1, \mathrm{M}^{-} / \mathrm{H}_{2}^{-} / 1$ [610].

Problem statement and solution. The paper poses the problem of finding solutions for the main characteristic - the average delay of claims in the queue in queuing systems formed by the distribution laws shifted to the right from the zero point: exponential (M), second-order Erlang (E2), second-order hyperexponential (H2). These shifted distribution laws, in contrast to the usual ones, will be denoted $\mathrm{M}^{-}, \mathrm{E}_{2}^{-}, \mathrm{H}_{2}^{-}$.

Let us consider the solution to the problem on the example of the system $E_{2}^{-} / E_{2}^{-} / 1$, which is described by the distribution laws of the input flow and service time in the form of density functions shifted to the right [6]:

$$
\begin{aligned}
& a(t)=4 \lambda^{2}\left(t-t_{0}\right) \mathbf{e}^{-2 \lambda\left(t-t_{0}\right)}, \\
& b(t)=4 \mu^{2}\left(t-t_{0}\right) \mathbf{e}^{-2 \mu\left(t-t_{0}\right)},
\end{aligned}
$$

where through $t_{0}>0$ the parameter of the shift of the distribution law is indicated.

The Laplace transform of functions (1), respectively, have the form:

$$
A^{*}(-s)=\left(\frac{2 \lambda}{2 \lambda-s}\right)^{2} \mathbf{e}^{t_{0} s} \quad B^{*}(s)=\left(\frac{2 \mu}{2 \mu+s}\right)^{2} \mathbf{e}^{-t_{0} s}
$$

Then the expression $A^{*}(-s)^{*} B^{*}(s)-1=\psi_{+}(s) / \psi_{-}(s)$ for the spectral expansion of the solution to the Lindley integral equation takes the following form:

$$
\begin{aligned}
& \frac{\psi_{+}(s)}{\psi_{-}(s)}=\left(\frac{2 \lambda}{2 \lambda-s}\right)^{2} \mathbf{e}^{t_{0} s} \times\left(\frac{2 \mu}{2 \mu+s}\right)^{2} \mathbf{e}^{-t_{0} s}-1= \\
& =\left(\frac{2 \lambda}{2 \lambda-s}\right)^{2}\left(\frac{2 \mu}{2 \mu+s}\right)^{2}-1
\end{aligned}
$$

The same spectral expansion will be for the ordinary system E2/E2/1, thus we establish that the spectral expansions of the solution of the Lindley integral equation for the QS formed by shifted distribution laws are invariant to the shift operation in the distribution laws.

We continue the spectral decomposition (3)

$$
\begin{aligned}
& \frac{\psi_{+}(s)}{\psi_{-}(s)}=\left(\frac{2 \lambda}{2 \lambda-s}\right)^{2}\left(\frac{2 \mu}{2 \mu+s}\right)^{2}-1= \\
& =\frac{16 \lambda^{2} \mu^{2}-(2 \lambda-s)^{2}(2 \mu+s)^{2}}{(2 \lambda-s)^{2}(2 \mu+s)^{2}}= \\
& =\frac{-s\left[s^{2}+2(\mu-\lambda) s-8 \lambda \mu\right][s+2(\mu-\lambda)]}{(2 \lambda-s)^{2}(2 \mu+s)^{2}} .
\end{aligned}
$$

Square trinomial of the numerator $s^{2}+(2 \mu-\lambda) s-8 \lambda \mu$ has one negative root and one positive root, since in case of a stable system $\lambda<\mu$ i.e. $(\mu-\lambda)>0$. For convenience, we denote them by $-s_{1}$ and $s_{3}$ :

$$
\begin{aligned}
& -s_{1}=-(\mu-\lambda)-\sqrt{(\mu-\lambda)^{2}+8 \lambda \mu}, \\
& s_{3}=-(\mu-\lambda)+\sqrt{(\mu-\lambda)^{2}+8 \lambda \mu} .
\end{aligned}
$$

For convenience, we denote them by $\psi_{+}(s) / \psi_{-}(s)$ :

$$
s=0 ;-s_{1}=-(\mu-\lambda)-\sqrt{(\mu-\lambda)^{2}+8 \lambda \mu} ;-s_{2}=-2(\mu-\lambda)
$$


(two negative roots and one positive root) $s_{3}=-(\mu-\lambda)+\sqrt{(\mu-\lambda)^{2}+8 \lambda \mu}$. Decomposition poles $\psi_{+}(s) / \psi_{-}(s): s=2 \lambda, s=-2 \mu$. Now, taking into account special conditions [1], we construct the components of the spectral expansion $\psi_{+}(s)$ and $\psi_{-}(s)$ :

$$
\psi_{+}(s)=\frac{s\left(s+s_{1}\right)\left(s+s_{2}\right)}{(2 \mu+s)^{2}} ; \quad \psi_{-}(s)=-\frac{(2 \lambda-s)^{2}}{\left(s-s_{3}\right)} .
$$

Further, using the method of spectral decomposition, we find the constant $\mathrm{K}$ :

$$
\begin{gathered}
K=\lim _{s \rightarrow 0} \frac{\psi_{+}(s)}{s}=\lim _{s \rightarrow 0} \frac{\left(s+s_{1}\right)\left(s+s_{2}\right)}{(2 \mu+s)^{2}}=\frac{s_{1} s_{2}}{4 \mu^{2}}, \\
s_{1}=(\mu-\lambda)+\sqrt{(\mu-\lambda)^{2}+8 \lambda \mu} \quad, s_{2}=2(\mu-\lambda) .
\end{gathered}
$$

hen

Hence the Laplace transform of the waiting time density function:

$$
W^{*}(s)=s K / \psi_{+}(s)=\frac{s_{1} s_{2}(2 \mu+s)^{2}}{4 \mu^{2}\left(s+s_{1}\right)\left(s+s_{2}\right)} .
$$

To find the average waiting time, we find the derivative of the function $W^{*}(s)$ with a minus sign at the point $s=0$ :

$$
\begin{aligned}
& -\left.\frac{d W^{*}(s)}{d(s)}\right|_{s=0}=\left.\frac{s_{1} s_{2}}{4 \mu^{2}}\left[\frac{4 \mu^{2}\left(s+s_{1}\right)-4 \mu s_{1} s_{2}}{s_{1}^{2} s_{2}^{2}}\right]\right|_{s=0}= \\
& =\frac{s_{1}+s_{2}}{s_{1} s_{2}}-\frac{1}{\mu} .
\end{aligned}
$$

Finally, the average latency of applications in the queue for the system $E_{2}^{-} / E_{2}^{-} / 1$

$$
\bar{W}=\frac{s_{1}+s_{2}}{s_{1} s_{2}}-\frac{1}{\mu}
$$

where the quantities

$$
s_{1}=(\mu-\lambda)+\sqrt{(\mu-\lambda)^{2}+8 \lambda \mu} \quad s_{2}=2(\mu-\lambda)
$$

are expressed through the parameters of distributions (1), which in turn will be determined through the numerical characteristics of distributions (1) by the method of moments.

Further, to solve the problem, we need the numerical characteristics of the distribution $\mathrm{E}_{2}^{-}$, which we will define through the Laplace transform.

The average value of the interval between arrivals is given by the first derivative of the Laplace transform with a minus sign at the point $s=0$ :

$$
\begin{aligned}
& -\left.\frac{d A^{*}(s)}{d s}\right|_{s=0}=\left.\left[\frac{8 \lambda^{2}}{(2 \lambda+s)^{3}} \mathbf{e}^{-t_{0} s}+\left(\frac{2 \lambda}{2 \lambda+s}\right)^{2} t_{0} \mathbf{e}^{t_{0} s}\right]\right|_{s=0}= \\
& =1 / \lambda+t_{0} .
\end{aligned}
$$

Hence the average interval between claims arrivals:

$$
\bar{\tau}_{\lambda}=\lambda^{-1}+t_{0}
$$

The second initial moment of the interval between arrivals is $\left.\frac{d^{2} A^{*}(s)}{d s^{2}}\right|_{s=0}=\frac{3}{2 \lambda^{2}}+2 \frac{t_{0}}{\lambda}+t_{0}^{2}$ $\overline{\tau_{\lambda}^{2}}=\frac{3}{2 \lambda^{2}}+2 \frac{t_{0}}{\lambda}+t_{0}^{2}$

Determine the square of the coefficient of variation $c_{\lambda}^{2}=\frac{\overline{\tau_{\lambda}^{2}}-\left(\overline{\tau_{\lambda}}\right)^{2}}{\left(\overline{\tau_{\lambda}}\right)^{2}}=\frac{1}{2\left(1+\lambda t_{0}\right)^{2}}$ coefficient of variation:

$$
c_{\lambda}=\left[\sqrt{2}\left(1+\lambda t_{0}\right)\right]^{-1}
$$

Note that for the usual distribution $E_{2}: \bar{\tau}_{\lambda}=\lambda^{-1}$, $c_{\lambda}=1 / \sqrt{2}$. Comparing numerical results for distributions $E_{2}$ and $\mathrm{E}_{2}^{-}$you can see the difference between them, obtained as a result of the shift of the distribution laws by the value $t_{0}>0$. The coefficient of variation $c_{\lambda}$ for distribution $\mathrm{E}_{2}^{-}$decreases with a shift in $\left(1+\lambda t_{0}\right)$ times compared to the coefficient $c_{\lambda}$ for the distribution of $E_{2}$. Taking into account the fact that the average delay of claims in the queue is related to the coefficients of variation of the arrival intervals and the service time by a quadratic dependence, this will provide a lower delay.

Similar expressions will take place for the numerical characteristics for the service law. Average service time is:

$$
\bar{\tau}_{\mu}=\mu^{-1}+t_{0}
$$

And the coefficient of variation:

$$
c_{\mu}=\left[\sqrt{2}\left(1+\mu t_{0}\right)\right]^{-1} \text {. }
$$

Then the algorithm for calculating the average time lag by formula (5) will be reduced to the following steps. one). We set as input parameters for calculating the system $E_{2}^{-} / E_{2}^{-} / 1$ the values obtained above $\bar{\tau}_{\lambda}, \bar{\tau}_{\mu}, c_{\lambda}, c_{\mu}$, and also the shift parameter $t_{0} 2$ ). From the equations of moments (7), (9) we determine the parameters of the distributions $\lambda$ and $\mu$, and from (8),

(10) coefficients of variation $c_{\lambda}, c_{\mu}$. 3). In the mathematical package Mathcad, we calculate the average delay in the queue using formula (5) for the ranges of variation of the coefficients of variation $c_{\lambda} \in(0,1 / \sqrt{2})$ and $c_{\mu} \in(0,1 / \sqrt{2})$, and also for the shift parameter $0<t_{0}<\bar{\tau}_{\mu}$. Comparative calculation results are shown in table. 4.

For the remaining five QSs with shifted distribution laws, solutions for the average queue delay were obtained in a similar 
way. For a summary of these results in table. 1 we will summarize the numerical characteristics of the considered distribution laws, which were used in the works [6-10].

Table 1

Numerical characteristics of distributions

\begin{tabular}{|c|c|c|c|}
\hline $\begin{array}{l}\text { Distr } \\
\text { ibuti } \\
\text { on }\end{array}$ & $\begin{array}{c}\text { First starting } \\
\text { moment } \bar{\tau}_{\lambda}\end{array}$ & $\begin{array}{c}\text { Second starting } \\
\text { moment }\end{array}$ & $\begin{array}{c}\text { Coefficient of variation } \\
\text { squared } c_{\lambda}^{2}\end{array}$ \\
\hline $\mathrm{M}$ & $1 \lambda$ & $2 / \lambda^{2}$ & 1 \\
\hline $\mathrm{E}_{2}$ & $1 / \lambda$ & $3 /\left(2 \lambda^{2}\right)$ & $1 / 2$ \\
\hline $\mathrm{H}_{2}$ & $\begin{array}{l}p / \lambda_{1}+ \\
+(1-p) / \lambda_{2}\end{array}$ & $2\left[p / \lambda_{1}^{2}+(1-p) / \lambda_{2}^{2}\right]$ & $\frac{\left(1-p^{2}\right) \lambda_{1}^{2}-2 \lambda_{1} \lambda_{2} p(1-p)+p(2-p) \lambda_{2}^{2}}{\left[(1-p) \lambda_{1}+p \lambda_{2}\right]^{2}}$ \\
\hline $\mathrm{M}^{-}$ & $\frac{1}{\lambda}+t_{0}$ & $2\left(\frac{1}{\lambda^{2}}+\frac{t_{0}}{\lambda}\right)+t_{0}^{2}$ & $\frac{1}{\left(1+\lambda t_{0}\right)^{2}}$ \\
\hline $\mathrm{E}_{2}^{-}$ & $\frac{1}{\lambda}+t_{0}$ & $\frac{3}{2 \lambda^{2}}+2 \frac{t_{0}}{\lambda}+t_{0}^{2}$ & $\frac{1}{2\left(1+\lambda t_{0}\right)^{2}}$ \\
\hline $\mathrm{H}_{2}^{-}$ & $\frac{p}{\lambda_{1}}+\frac{(1-p)}{\lambda_{2}}+t_{0}$ & $\begin{array}{c}t_{0}^{2}+2 t_{0}\left[\frac{p}{\lambda_{1}}+\frac{(1-p)}{\lambda_{2}}\right]+ \\
+2\left[\frac{p}{\lambda_{1}^{2}}+\frac{(1-p)}{\lambda_{2}^{2}}\right]\end{array}$ & $\frac{\left(1-p^{2}\right) \lambda_{1}^{2}-2 \lambda_{1} \lambda_{2} p(1-p)+p(2-p) \lambda_{2}^{2}}{\left[t_{0} \lambda_{1} \lambda_{2}+(1-p) \lambda_{1}+p \lambda_{2}\right]^{2}}$ \\
\hline
\end{tabular}

The numerical characteristics of the shifted distributions (Table 1) clearly indicate a significant influence of the shift parameter $\mathrm{t} 0$ on them, therefore, the main characteristic of the QS the average delay of requests in the queue will be a function of the shift parameter. This fact will be confirmed by the results of computational experiments below.

Now we need to determine the unknown parameters of these distributions. These parameters are also obtained in [6-10] and for the cases of the distribution density functions of the intervals of input flows $a(t)$ are summarized in Table 2.

Table 2

Parameters of shifted distributions obtained by the method of moments

\begin{tabular}{|c|c|c|c|c|}
\hline \begin{tabular}{|l} 
Distri \\
butio \\
$\mathrm{n}$ \\
\end{tabular} & Density $a(t)$ & \multicolumn{3}{|c|}{ Parameters $p, \lambda, \lambda_{1}, \lambda_{2}$} \\
\hline $\mathrm{M}^{-}$ & $\lambda \mathbf{e}^{-\lambda\left(t-t_{0}\right)}$ & \multicolumn{3}{|c|}{$\lambda=\frac{1}{\overline{\tau_{\lambda}-t_{0}}}$} \\
\hline$E_{2}^{-}$ & $4 \lambda^{2}\left(t-t_{0}\right) \mathbf{e}^{-2 \lambda\left(t-t_{0}\right)}$ & \multicolumn{3}{|c|}{$\lambda=\frac{1}{\bar{\tau}_{\lambda}-t_{0}}$} \\
\hline $\mathrm{H}_{2}^{-}$ & $\begin{array}{l}p \lambda_{1} \mathrm{e}^{-\lambda_{1}\left(t-t_{0}\right)}+ \\
+(1-p) \lambda_{2} \mathrm{e}^{-\lambda_{2}\left(t-t_{0}\right)}\end{array}$ & $\begin{array}{l}p=\frac{1}{2} \pm \\
\pm \sqrt{\frac{1}{4}-\frac{\left(\bar{\tau}_{\lambda}-t_{0}\right)^{2}}{2\left[\left(\bar{\tau}_{\lambda}-t_{0}\right)^{2}+c_{\lambda}^{2} \bar{\tau}_{\lambda}^{2}\right]}}\end{array}$ & $\lambda_{1}=\frac{2 p}{\left(\bar{\tau}_{\lambda}-t_{0}\right)}$ & $\lambda_{2}=\frac{2(1-p)}{\left(\bar{\tau}_{\lambda}-t_{0}\right)}$ \\
\hline
\end{tabular}

Similar parameters for the distributions of the service time $b(t)$ will take place by replacing $\lambda$ on $\mu$.

Table 3 shows the Laplace transforms obtained in [5-9] for the density function of the waiting time in the queue in the systems under consideration, the components of the spectral expansions of the solution to the Lindley integral equation, as well as calculation formulas for the average queue delay in the corresponding systems.
Table 3

Laplace transforms of the waiting time density function, components of spectral expansions of the ILE solution, calculated expressions for the average waiting time

\begin{tabular}{|c|c|c|}
\hline QS & \begin{tabular}{|c|} 
Laplace transforms \\
of the waiting time density \\
function and spectral decompo- \\
sition components \\
\end{tabular} & $\begin{array}{l}\text { Calculated Expressions } \\
\text { for Average Latency }\end{array}$ \\
\hline $\mathrm{E}_{2}^{-} / \mathrm{E}_{2}^{-} / 1$ & $\begin{array}{c}W^{*}(s)=\frac{s_{1} s_{2}(2 \mu+s)^{2}}{4 \mu^{2} s\left(s+s_{1}\right)\left(s+s_{2}\right)} \\
\psi_{+}(s)=\frac{s\left(s+s_{1}\right)\left(s+s_{2}\right)}{(2 \mu+s)^{2}}, \\
\psi_{-}(s)=-\frac{(2 \lambda-s)^{2}}{\left(s-s_{3}\right)}\end{array}$ & $\begin{array}{l}\bar{W}=\frac{s_{1}+s_{2}}{s_{1} s_{2}}-\frac{1}{\mu}, \text { when } \\
s_{1}=(\mu-\lambda)+\sqrt{(\mu-\lambda)^{2}+8 \lambda \mu}, \\
s_{2}=2(\mu-\lambda) .\end{array}$ \\
\hline $\mathrm{M}^{-} / \mathrm{E}_{2}^{-} / 1$ & $\begin{array}{c}W^{*}(s)=\frac{(1-\rho)(2 \mu+s)^{2}}{\left(s+s_{1}\right)\left(s+s_{2}\right)}, \\
\psi_{+}(s)=\frac{s\left(s+s_{1}\right)\left(s+s_{2}\right)}{(2 \mu+s)^{2}}, \\
\psi_{-}(s)=\lambda-s\end{array}$ & $\bar{W}=\frac{3 \rho\left(\bar{\tau}_{\mu}-t_{0}\right)}{4(1-\rho)}$ \\
\hline $\mathrm{E}_{2}^{-} / \mathrm{M}^{-} / 1$ & $\begin{array}{l}W^{*}(s)=\frac{s_{1}(s+\mu)}{\mu\left(s+s_{1}\right)}, \\
\psi_{+}(s)=\frac{s\left(s+s_{1}\right)}{s+\mu}, \\
\psi_{-}(s)=-\frac{(2 \lambda-s)^{2}}{s-s_{2}}\end{array}$ & $\begin{array}{l}\bar{W}=1 / s_{1}-1 / \mu, \text { when } \\
s_{1}=(\mu-4 \lambda) / 2+ \\
+\sqrt{[(\mu-4 \lambda) / 2]^{2}+4 \lambda(\mu-\lambda)}\end{array}$ \\
\hline $\mathrm{M}^{-} / \mathrm{H}_{2}^{-} / 1$ & $\begin{array}{c}W^{*}(s)=\frac{s_{1} s_{2}\left(s+\mu_{1}\right)\left(s+\mu_{2}\right)}{\mu_{1} \mu_{2}\left(s+s_{1}\right)\left(s+s_{2}\right)} \\
\psi_{+}(s)=\frac{s\left(s+s_{1}\right)\left(s+s_{2}\right)}{\left(s+\mu_{1}\right)\left(s+\mu_{2}\right)} \\
\psi_{-}(s)=\lambda-s\end{array}$ & $\begin{array}{l}\bar{W}=\frac{s_{1}+s_{2}}{s_{1} s_{2}}-\frac{\mu_{1}+\mu_{2}}{\mu_{1} \mu_{2}}, \\
\text { when } s_{1}, s_{2} \text { the absolute } \\
\text { values of the negative zeros } \\
\text { of the numerator of the } \\
\text { function } \psi_{+}(s) / \psi_{-}(s)\end{array}$ \\
\hline $\mathrm{H}_{2}^{-} / \mathrm{M}^{-} / 1$ & $\begin{array}{c}W^{*}(s)=\frac{s_{1}(s+\mu)}{\mu\left(s+s_{1}\right)}, \\
\psi_{+}(s)=\frac{s\left(s+s_{1}\right)}{s+\mu}, \\
\psi_{-}(s)=\frac{\left(s-\lambda_{1}\right)\left(\lambda_{2}-s\right)}{s-s_{2}}\end{array}$ & $\begin{array}{l}\bar{W}=1 / s_{1}-1 / \mu \text {, when } s_{1} \\
\text { the absolute value of the } \\
\text { negative zero of the numer- } \\
\text { ator of the function } \\
\psi_{+}(s) / \psi_{-}(s)\end{array}$ \\
\hline $\mathrm{H}_{2}^{-} / \mathrm{H}_{2}^{-} / 1$ & $\begin{array}{c}W^{*}(s)=\frac{s_{1} s_{2}\left(s+\mu_{1}\right)\left(s+\mu_{2}\right)}{\mu_{1} \mu_{2}\left(s+s_{1}\right)\left(s+s_{2}\right)} \\
\psi_{+}(s)=\frac{s\left(s+s_{1}\right)\left(s+s_{2}\right)}{\left(s+\mu_{1}\right)\left(s+\mu_{2}\right)} \\
\psi_{-}(s)=\frac{\left(s-\lambda_{1}\right)\left(\lambda_{2}-s\right)}{s-s_{3}}\end{array}$ & $\begin{array}{l}\bar{W}=\frac{1}{s_{1}}+\frac{1}{s_{2}}-\frac{1}{\mu_{1}}-\frac{1}{\mu_{2}}, \\
\text { when } s_{1}, s_{2} \text { the absolute } \\
\text { values of the negative zeros } \\
\text { of the numerator of the } \\
\text { function } \psi_{+}(s) / \psi_{-}(s)\end{array}$ \\
\hline
\end{tabular}

A detailed description of the algorithms for calculating the average waiting time for the systems under consideration can be found in [6-10]. 


\section{Results of computational experiments}

Table 4-5 for an example of demonstration of the developed algorithms, the calculation data in the MathCAD package for systems $\mathrm{E}_{2}^{-} / \mathrm{E}_{2}^{-} / 1, \mathrm{H}_{2}^{-} / \mathrm{H}_{2}^{-} / 1$ for light, medium and high load cases $\rho=0,1 ; 0,5 ; 0,9$ for a wide range of variation coefficients $c_{\lambda}, c_{\mu}$ and the shift parameter $t_{0}$. The results for queueing systems with time lags are compared with those for conventional systems. This will make it possible to quantify how much the average latency of applications in the queue in a queueing system with time lags decreases. Load factor $\rho$ in table 4-5 is determined by the ratio of average intervals $\rho=\bar{\tau}_{\mu} / \bar{\tau}_{\lambda}$ as well as in simulation modeling. For convenience, the calculations used the normalized service time $\bar{\tau}_{\mu}=1$.

Table 4

Experimental results for QS $\mathrm{E}_{2}^{-} / \mathrm{E}_{2}^{-} / 1$ and $\mathrm{E}_{2} / \mathrm{E}_{2} / 1$

\begin{tabular}{|c|c|c|c|c|c|}
\hline \multicolumn{4}{|c|}{ Input parameters } & \multicolumn{2}{|c|}{ Average waiting time } \\
\hline$\rho$ & $c_{\lambda}$ & $c_{\mu}$ & $t_{0}$ & $\begin{array}{c}\text { for the system } \\
E_{2}^{-} / E_{2}^{-} / 1\end{array}$ & $\begin{array}{c}\text { for the system } \\
\qquad E_{2} / E_{2} / 1\end{array}$ \\
\hline \multirow{4}{*}{0,1} & 0,643 & 0,071 & 0,9 & 0,000 & \multirow{4}{*}{0,017} \\
\hline & 0,672 & 0,354 & 0,5 & 0,002 & \\
\hline & 0,700 & 0,636 & 0,1 & 0,013 & \\
\hline & 0,706 & 0,700 & 0,01 & 0,016 & \\
\hline \multirow{4}{*}{0,5} & 0,389 & 0,071 & 0,9 & 0,001 & \multirow{4}{*}{0,390} \\
\hline & 0,530 & 0,354 & 0,5 & 0,081 & \\
\hline & 0,672 & 0,636 & 0,1 & 0,309 & \\
\hline & 0,704 & 0,700 & 0,01 & 0,382 & \\
\hline \multirow{4}{*}{0,9} & 0,134 & 0,071 & 0,9 & 0,034 & \multirow{4}{*}{4,359} \\
\hline & 0,389 & 0,354 & 0,5 & 1,057 & \\
\hline & 0,643 & 0,636 & 0,1 & 3,519 & \\
\hline & 0,701 & 0,700 & 0,01 & 4,271 & \\
\hline
\end{tabular}

Table 5

Experimental results for QS $\mathrm{H}_{2}^{-} / \mathrm{H}_{2}^{-} / 1$ and $\mathrm{H}_{2} / \mathrm{H}_{2} / 1$

\begin{tabular}{|c|c|c|c|c|c|}
\hline \multicolumn{2}{|c|}{ Input parameters } & \multicolumn{4}{|c|}{ Average waiting time } \\
\hline \multirow{2}{*}{$\rho$} & \multirow{2}{*}{$\left(c_{\lambda}, c_{\mu}\right)$} & \multicolumn{3}{|c|}{ for the system $\mathrm{H}_{2}^{-} / \mathrm{H}_{2}^{-} / 1$} & \multirow{2}{*}{$\begin{array}{l}\text { for the system } \\
\qquad \mathrm{H}_{2} / \mathrm{H}_{2} / 1\end{array}$} \\
\hline & & $t_{0}=0,9$ & $t_{0}=0,5$ & $t_{0}=0,1$ & \\
\hline \multirow{4}{*}{0,1} & $(1,1)$ & 0,06 & 0,07 & 0,10 & 0,11 \\
\hline & $(2,2)$ & 0,28 & 0,36 & 0,42 & 0,45 \\
\hline & $(4,4)$ & 1,19 & 1,54 & 1,73 & 1,78 \\
\hline & $(8,8)$ & 4,81 & 6,31 & 6,97 & 7,11 \\
\hline \multirow{4}{*}{0,5} & $(1,1)$ & 0,56 & 0,75 & 0,95 & 1,00 \\
\hline & $(2,2)$ & 2,31 & 3,13 & 3,87 & 4,04 \\
\hline & $(4,4)$ & 9,29 & 12,61 & 15,45 & 16,13 \\
\hline & $(8,8)$ & 37,22 & 50,50 & 61,54 & 64,18 \\
\hline \multirow{4}{*}{0,9} & $(1,1)$ & 6,04 & 8,30 & 8,91 & 9,00 \\
\hline & $(2,2)$ & 24,14 & 33,22 & 35,84 & 36,20 \\
\hline & $(4,4)$ & 96,51 & 132,30 & 143,27 & 144,83 \\
\hline & $(8,8)$ & 386,03 & 527,68 & 571,47 & 577,86 \\
\hline
\end{tabular}

\section{Conclusions}

The article presents the spectral expansions of the solution to the Lindley integral equation for the six considered QSs and the calculation formulas obtained on their basis for the average delay in the queue. Calculation results. as expected, confirm that the decrease in the coefficients of variation $c_{\lambda}$ and $c_{\mu}$ by introducing the shift parameter $t_{0}>0$ into the laws of distribution of the input flow and service time entails a decrease in the average delay in queueing systems with time lags by several times.

The adequacy of the presented results, on the one hand, is confirmed by the fact that as the shift parameter tends $t_{0}$ to zero, the average delay of claims in the queue in systems with time lags tends to its value in a conventional system. On the other hand, the adequacy of the presented mathematical models of queueing systems with time lags is achieved by the correct use of the classical method of spectral decomposition of the Lindley integral equation for the considered systems.

The results obtained can be used in the modern theory of teletraffic as a practical application in modeling delays in real data transmission systems. To do this, it is necessary to know the numerical characteristics of the time intervals of the incoming traffic, which is not difficult to implement in the presence of modern traffic analyzers.

\section{References}

1. Kleinrock L. (1979). Queuing theory, Moscow, Mashinostroeinie Publ, 432 p.

2. Brannstrom N.A. (2004). Queueing Theory analysis of wireless radio systems, Appllied to HS-DSCH, Lulea university of technology, $79 \mathrm{p}$.

3. Tarasov V.N., Bahareva N.F., Konnov A.L., Ushakov Yu.A. (2008). Proektirovanie i modelirovanie setej EVM v sisteme Opnet Modeler. Laboratornyj praktikum. Samara, $233 \mathrm{p}$.

4. Riverbed to Acquire OPNET Technologies, Inc., 2015. - Available at: www.riverbed.com/about/news-articles/press-releases/ riverbed-to-acquire-opnettechnologies-inc.html.

5. Tarasov V.N. (2018). Extension of the Class of Queueing Systems with Delay, Automation and Remote Control, vol. 79, no. 12, pp. 2147-2157, DOI: $10.1134 / \mathrm{S} 0005117918120056$

6. Tarasov V.N., Bahareva N.F., Ahmetshina E.G. (2018). Analiz novoj sistemy massovogo obsluzhivaniya $E_{2} / E_{2} / 1 \quad s$ zapazdyvaniem, Infokommunikacionnye tekhnologii, No.3. P. 277-282.

7. Tarasov V.N., Akhmetshina E.G. (2018). The average waiting time in a queuing system $\mathrm{H}_{2} / \mathrm{H}_{2} / 1$ with delay, Vestn. Samar. Gos. Tekhn. Univ., Ser. Fiz.-Mat. Nauki, No. 4. P. 702-713

8. Tarasov V.N., Bahareva N.F., Ahmetshina E.G. (2018). Sistema massovogo obsluzhivaniya $E_{2} / \mathrm{M} / 1$ s obychnymi i sdvinutymi vhodnymi raspredeleniyami, Infokommunikacionnye tekhnologii, No. 4. P. 387-392.

9. Tarasov V.N., Bahareva N.F., Ahmetshina E.G. (2020). Issledovanie dvuh sistem massovogo obsluzhivaniya $\mathrm{M} / \mathrm{E}_{2} / 1 \mathrm{~s}$ obychnymi so sdvinutymi vhodnymi raspredeleniyami, Infokommunikacionnye tekhnologii, No.1. P. 33-38.

10. Tarasov V.N., Bahareva N.F., Ahmetshina E.G. (2020). Modeli teletrafika na osnove dvojstvennyh sistem $\mathrm{s}$ zapazdyvaniem $\mathrm{s}$ gipereksponencial'nymi i eksponencial'nymi raspredeleniyami, Informacionnye tekhnologii, No. 4. P. 195-202.

11. Whitt W. (1982). Approximating a point process by a renewal process: two basic methods, Operation Research, vol. 30, no.1. P. 125-147.

12. Aliev T.I. (2013). Approksimaciya veroyatnostnyh raspredelenij v modelyah massovogo obsluzhivaniya, Nauchno-tekhnicheskij vestnik informacionnyh tekhnologij, mekhaniki i optiki, vol. 84. No. 2. P. 88-93.

13. Bocharov P.P., Pechinkin A.V. (1995). Teoriya massovogo obsluzhivaniya, Moscow, Publishing House of Peoples' Friendship University, 529 p.

14. Novitzky S., Pender J., Rand R.H. (2019). Wesson E. Nonlinear Dynamics in Queueing Theory: Determining the Size of Oscillations in Queues with Delay, SIAM J. Appl. Dyn. Syst., 18-1 2019, vol. 18, no. 1, pp. 279-311, DOI: https://doi.org/10.1137/18M1170637

15. Adan I., D'Auria B., Kella O. (2019). Special volume on 'Recent Developments in Queueing Theory' of the third ECQT conference, Queueing Systems, 2019, pp. 1-190, DOI: https://doi.org/10.1007/s11134-019-09630-1.

16. Legros B. (2018). M/G/1 queue with event-dependent arrival rates, Queueing Systems, vol. 89, no. 3, pp. 269-301, DOI https://doi.org/10.1007/s11134-017-9557-7.

17. Bazhba M., Blanchet J., Rhee CH. et al. (2019). Queue with heavy-tailed Weibull service times, Queueing Systems, vol. 93, no. 11, pp. 132, DOI: https://doi.org/10.1007/s11134-019-09640-z 


\section{МОДЕЛИРОВАНИЕ СИСТЕМ ПЕРЕДАЧИ ДАННЫХ С ИСПОЛЬЗОВАНИЕМ СОВРЕМЕННЫХ ИНФОРМАЦИОННЫХ ТЕХНОЛОГИЙ}

Ахметиина Элеонора Газинуровна, Поволжский государственный университет телекоммуникаций и информатики, 2. Самара, Россия, elyamalusha@mail.ru

\section{Аннотация}

При моделировании систем передачи данных различного назначения, в том числе компьютерных и телекоммуникационных сетей широко используются обе составляющие математического моделирования. Это имитационное моделирование и аналитическое моделирование на основе теории массового обслуживания. При этом исследователи всегда могут сопоставить результаты, полученные путем имитационного и аналитического моделирования. Из современных технологий имитационного моделирования можно выделить технологии IT GURU Academic Edition, представленные программными продуктами Opnet Modeler и Riverbed Modeler c мощными графическими редакторами. Графические редакторы позволяют создавать имитационные модели систем передачи данных любой сложности, а запуск и прогон их моделей получать статистики основных показателей производительности этих систем. Сопоставление результатов имитации с результатами систем массового обслуживания (CMO) типа G/G/I позволяет оценить адекватность тех и других математических моделей. В данной статье обобщены результаты по публикациям автора по системам G/G/I на основе сдвинутых во времени законов распределений, таких как: экспоненциальный, гиперэкспоненциальный и распределение Эрланга. Таким образом, данные законы распределений для используемых случайных величин обеспечивают коэффициенты вариации меньше, равно и больше единицы. Этот факт с точки зрения теории массового обслуживания важен, т.к. средняя задержка заявок в системе напрямую зависит от коэффициентов вариаций временных интервалов поступления и обслуживания заявок.

Ключевые слова: технологии IT GURU, имитационное моделирование, аналитическое моделирование, СMO с запаздыванием во времени, средняя задержка.

\section{Литература}

І. Клейнрок Л. Теория массового обслуживания. Пер. с англ. под редакцией В.И. Неймана М.: Машиностроение, 1979. 432 с.

2. Brannstrom N. A Queueing Theory analysis of wireless radio systems // Appllied to HS-DSCH. Lulea university of technology, 2004. 79 p.

3. Тарасов В.Н., Бахарева Н.Ф., Кононов А.Л., Ушаков Ю.А. Проектирование и моделирование сетей ЭВМ в системе Орnet Мodeler. Лабораторный практикум. Самара, 2008. 233 с.

4. Riverbed to Acquire OPNET Technologies, Inc. [Электронный ресурс] / 2015. - Режим доступа: www.riverbed.com/about/news-articles/press-releases/ riverbed-to-acquire-opnet-technologies-inc.html, свободный. Загл. с экрана.

5. Тарасов В.Н. Расширение класса систем массового обслуживания с запаздыванием // Автоматика и телемеханика. 2018. №12. С.57-70.

6. Тарасов В.Н., Бахарева Н.Ф., Ахметшина Э.Г. Анализ новой системы массового обслуживания Е2/Е2/I с запаздыванием // Инфокоммуникационные технологии. 2018. №3. С.277-282.

7. Тарасов В.Н., Ахметшина Э.Г. Среднее время ожидания в системе массового обслуживания Н2/H2/I с запаздыванием // Вестник СамГТУ серия физмат.науки. 2018. №4. С. 702-7І3.

8. Тарасов В.Н., Бахарева Н.Ф., Ахметшина Э.Г. Система массового обслуживания Е2/М/I с обычными и сдвинутыми входными распределениями // Инфокоммуникационные технологии. 2018. №4. С. 387-392.

9. Тарасов В.Н., Бахарева Н.Ф., Ахметшина Э.Г. Исследование двух систем массового обслуживания М/Е2/I с обычными и со сдвинутыми входными распределениями // Инфокоммуникационные технологии. 2020. №I. С. 33-38.

10. Тарасов В.Н., Бахарева Н.Ф., Ахметшина Э.Г. Модели телетрафика на основе двойственных систем с запаздыванием с гиперэкспоненциальными и экспоненциальными распределениями // Информационные технологии. 2020. № 4. С. 195-202.

II. Алиев Т.И. Аппроксимация вероятностных распределений в моделях массового обслуживания // Научно-технический вестник информационных технологий, механики и оптики. 2013. № 2(84). С. 88-93.

12. Whitt W. Approximating a point process by a renewal process: two basic methods // Operation Research. 1982. N. I. P. I25-I47.

13. Бочаров П.П., Печинкин А.В. Теория массового обслуживания. М.: Изд-во РУДН, 1995. 529 с.

14. Novitzky S., Pender J., Rand R.H., Wesson E. Nonlinear Dynamics in Queueing Theory: Determining the Size of Oscillations in Queues with Delay /I SIAM J. Appl. Dyn. Syst. 2019. Vol. 18, N.I. P. 279-3II.

I5. Adan I., D'Auria B., Kella O. Special volume on 'Recent Developments in Queueing Theory' of the third ECQT conference // Queueing Systems. 2019. No. I. P. I-I90. DOI: https://doi.org/I0.1007/s I I I34-019-09630-I.

16. Legros B. M/G/I queue with event-dependent arrival rates // Queueing Systems. 20I8. Vol. 89, No. 3. P. 269-30I. DOI: https://doi.org/I0. I007/s I I I34017-9557-7

17. Bazhba M., Blanchet J., Rhee CH., et al. Queue with heavy-tailed Weibull service times // Queueing Systems. 2019. Vol. 93, No. II. P. I-32. DOI: https://doi.org/I0.1007/sI I I34-019-09640-z

Информация об авторе:

Ахметшина Элеонора Газинуровна, аспирант кафедры ПОУТС, Поволжский государственный университет телекоммуникаций и информатики, 2. Самара, Россия 